\title{
PREDBEŽNÉ VYHODNOTENIE KERAMIKY Z JERUZALEMSKÉHO VRCHU V KEŽMARKU
}

\author{
Andrea Námerová - Marta Kučerová
}

DOI: https://doi.org/10.31577/szausav.2019.suppl.1.20

Keywords: North Slovakia, Spiš region, La Tène Period, Púchov culture, settlement, pottery

\section{Preliminary evaluation of ceramic collection from Jerusalem hill site in Kežmarok}

Jerusalem hill (Jeruzalemský vrch) belongs to important archaeological sites in the Spiš region. The site has been identified at the latest in the $19^{\text {th }}$ century, but has never been studied systematically. The largest part of the material remains can be ascribed to the Iron Age - to the Púchov culture more precisely. This study focuses on pottery finds and objects from ceramic, such as spindle whorls, or ceramic wheel, or other artefacts made from clay found at Jerusalem hill. From the site come also horned sherds - bowl or jug handles, which are characteristic for the Late Hallstatt and the Early La Tène Period in Slovakia as well as in other regions in Central and South Europe. This contribution is the first step to further study, deeper analysis and comparison of material mainly from other Spiš sites, but also in a broader context (Liptov and other regions in Slovakia, Poland).

\section{ÚVOD}

Jeruzalemský vrch je predmetom archeologického skúmania už minimálne jedno storočie (Baráthová a i. 2013, 38-46; Greisiger 1890, 56-58; Hefty 1925, 78, 79; Lipták 1934, 6, 7; Spöttl 1885, 42-48). Okrem povrchových zberov, ${ }^{1}$ záchranných výskumov formou sledovania a dokumentovania výkopov rôzneho charakteru sa na lokalite uskutočnilo aj niekol'ko sondážnych výskumov s obmedzeným rozsahom (Giertlová/Mihok 2001, 75, 76; Giertlová/Soják/Wavrek 2000, 71, 72; Kučerová 2017), pričom čast̉ z nich viedli amatérski nadšenci ešte v prvej polovici 20. stor. (Hajts 1926, 19, 20; Kieferov výskum v roku 1949 - Baráthová a i. 2013, 43). V súčasnosti sú viaceré polohy zdevastované novodobou výstavbou (Kiefer 1974), a tiež predošlou tažbou kameňa v 15.-17. stor.

Podla prevažujúcej keramiky z obdobia púchovskej kultúry môžeme na základe doterajších nálezov lokalitu označit za jedno z opevnených sídlisk púchovskej kultúry na Spiši s počiatkami v predpúchovskom horizonte (Miroššayová 1992, 133-138; Novotný/Novotná/Kovalč́k 1991, 41; Pieta 2003, 150). V nálezovom materiáli dominujú predovšetkým nálezy keramiky, no aj zvieracie kosti, mazanica alebo do sklovita prepálená hlina. $Z$ drobných predmetov zo skla sú to perly a zlomok náramku, z kovových nálezov, okrem starších nálezov mincí, ${ }^{2}$ ojedinelé drobné predmety z bronzu a zo železa. K významnejším kovovým artefaktom patrí fragment bronzového diadému typu Istebné (Soják 2015, 154-159).

Predkladaný príspevok je zameraný na predbežné zhodnotenie keramického materiálu z lokality, so zretelom na nálezy z posledného výskumu v roku 2013, zohladňujúc však aj staršie výskumy a zbierky Múzea v Kežmarku.

1 Do tejto kategórie je zaradený aj materiál zachránený Ing. L. Kieferom počas stavebných prác na amfiteátri a neskôr pri výstavbe športového areálu s hotelom Štart v 60. až 70. rokoch 20. stor. (Kiefer 1974).

2 Predovšetkým zo zbierky Dr. Greisigera, v súčasnosti uložené v Slovenskom národnom múzeu v Bratislave. 


\section{CHARAKTERISTIKA LOKALITY}

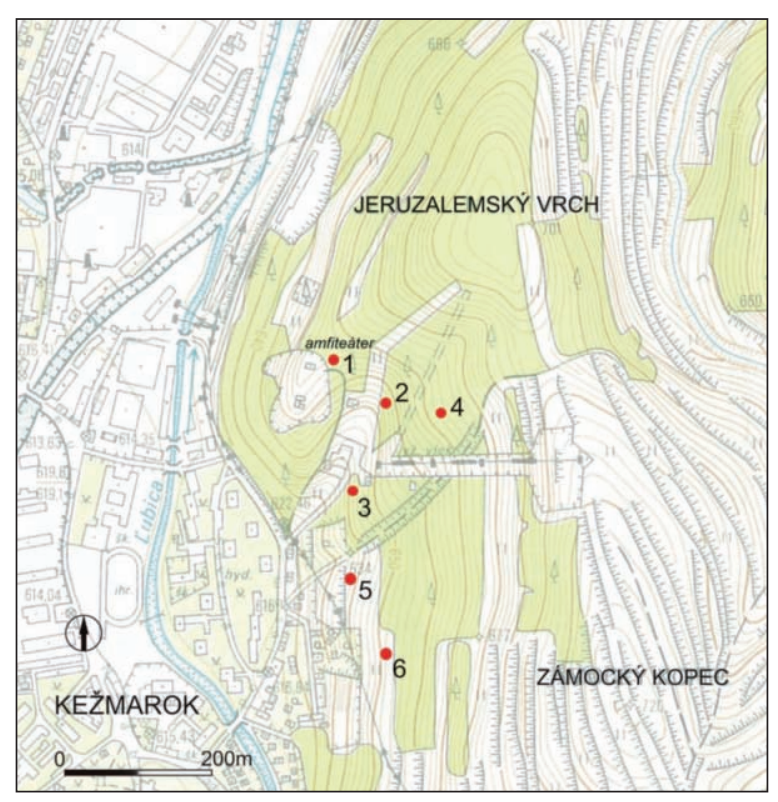

Obr. 1. Kežmarok, poloha Jeruzalemský vrch (okr. Kežmarok). Topografická mapa 1 : 10000 s vyznačenými polohami sondážnych výskumov a dokumentovaných výkopov. 1 - amfiteáter (sondážny výskum; Kučerová 2017); 2 - hotel Štart (sondážny výskum; Giertlová 1998a; 2000; Kučerová 2017); 3 - plynová ryha pod hotelom Štart (priečny rez terasou; Giertlová 2000); 4 - medzi zjazdovkami, SV od hotela Štart (výkop s nálezom nádoby; Kučerová 2016); 5 - strelnica-Oravcova lúka (parc. č. 1476, sondážny výskum; Giertlová 1998b); 6 - strelnica-Oravcova lúka (parc. č. 1462, sondážny výskum; Giertlová 1998b).
Jeruzalemský vrch sa nachádza severne od historického jadra Kežmarku na pravej strane Lubického potoka nad jeho sútokom s riekou Poprad. Lokalita leží na západnom okraji Levočských vrchov. Na mape (obr. 1) sa takto označuje členitejší kopec s vrcholom vo výške $701 \mathrm{~m} \mathrm{n}$. m., ktorý sa zvažuje severným, západným a východným smerom a na juhu prechádza do hrebeňa tzv. Zámockého kopca (označovaného aj ako Hradný vrch). Hranica medzi oboma vrchmi sa nachádza niekde v mieste starej cesty vedúcej východným smerom od ulice Pod Lesom, s výrazným úvozom dodnes viditelným $\mathrm{v}$ teréne, zachyteným aj na topografickej mape (obr. 1). Na západnom úpätí vybieha z masívu Jeruzalemského vrchu menej výrazný ostrožný výbežok ( $v$ súčasnosti sa tu nachádza amfiteáter), ktorý sám osebe predstavuje pôvodnú opevnenú výšinnú polohu. V jeho blízkosti sa koncentrujú pozostatky osídlenia na svahoch Jeruzalemského vrchu a na terasách Zámockého kopca, v nadmorskej výške od 622 do približne $670 \mathrm{~m}$. V súvislosti s používaným názvoslovím treba konštatovat, že v odbornej literatúre sa aj nálezy z polôh na terasovito upravenom západnom úbočí Zámockého kopca, ktoré sa tradične označuje ako Strelnica, uvádzajú ako nálezy z Jeruzalemského vrchu (napr. Soják 2015). Z historických mapových zobrazení, ${ }^{3}$ ako aj historických opisov je zrejmé, ${ }^{4}$ že pojmom Jeruzalemský vrch sa pôvodne označoval len vyššie spomínaný ostrožný výbežok (666 m n. m.) s pozostatkami opevnenia. Postupným spresňovaním rozsahu osídlenia $\mathrm{v}$ okolí hradiska sa tento názov začal vztahovat’ na všetky zistené už zmienené polohy s výskytom archeologických nálezov.

\section{ARCHEOLOGICKÝ POTENCIÁL LOKALITY}

Okrem sondážnych archeologických výskumov s obmedzeným rozsahom, boli na lokalite sledované aj iné zásahy do terénu. Juhozápadne od prístupovej cesty k hotelu Štart to bol výkop plynovej ryhy (obr. 1, poloha 3) vedený kolmo na hranu zalesnenej terasy, čím vznikol jej priečny rez (obr. 2; Giertlová 2000). Pod pôdnym pokryvom, ktorý na lokalite tvoria hnedé lesné pôdy vytvorené zo zvetralín pieskovcovoílovcových hornín flyšového podložia (Gross 1999; http://wwww.podnemapy.skd), sa nachádzala tmavohnedá hlinitá vrstva s prímesou uhlíkov, v ktorej sa koncentrovali nálezy (obr. 2, vrstva 2B).

Druhý výkop, ktorý bol výsledkom detskej hry - budovania bunkra (Kučerová 2016), bol zdokumentovaný v zalesnenom priestore medzi dvomi zjazdovkami nachádzajúcimi sa severne a západne od hotela Štart (obr. 1, poloha 4), kde neboli pozorované žiadne terasovité úpravy. V profile výkopu sa pod lesnou pôdou nachádzala $0,4 \mathrm{~m}$ mohutná súdržná tmavo sivá ílovitá vrstva, ktorá ležala na zvetranom podloží (obr. 2, vrstva 2C) a z ktorej pochádza nielen nádoba (tab. III: 6), ale aj d’alšie nepočetné zlomky keramiky.

\footnotetext{
Pozri 2. vojenské mapovanie, dostupné napríklad na http://mapire.eu/hu.

4 Najstarší známy je opis od Georga Bohusa (1687-1722), vydaný tlačou v roku 1919 (Bohus 1919, 105).
} 


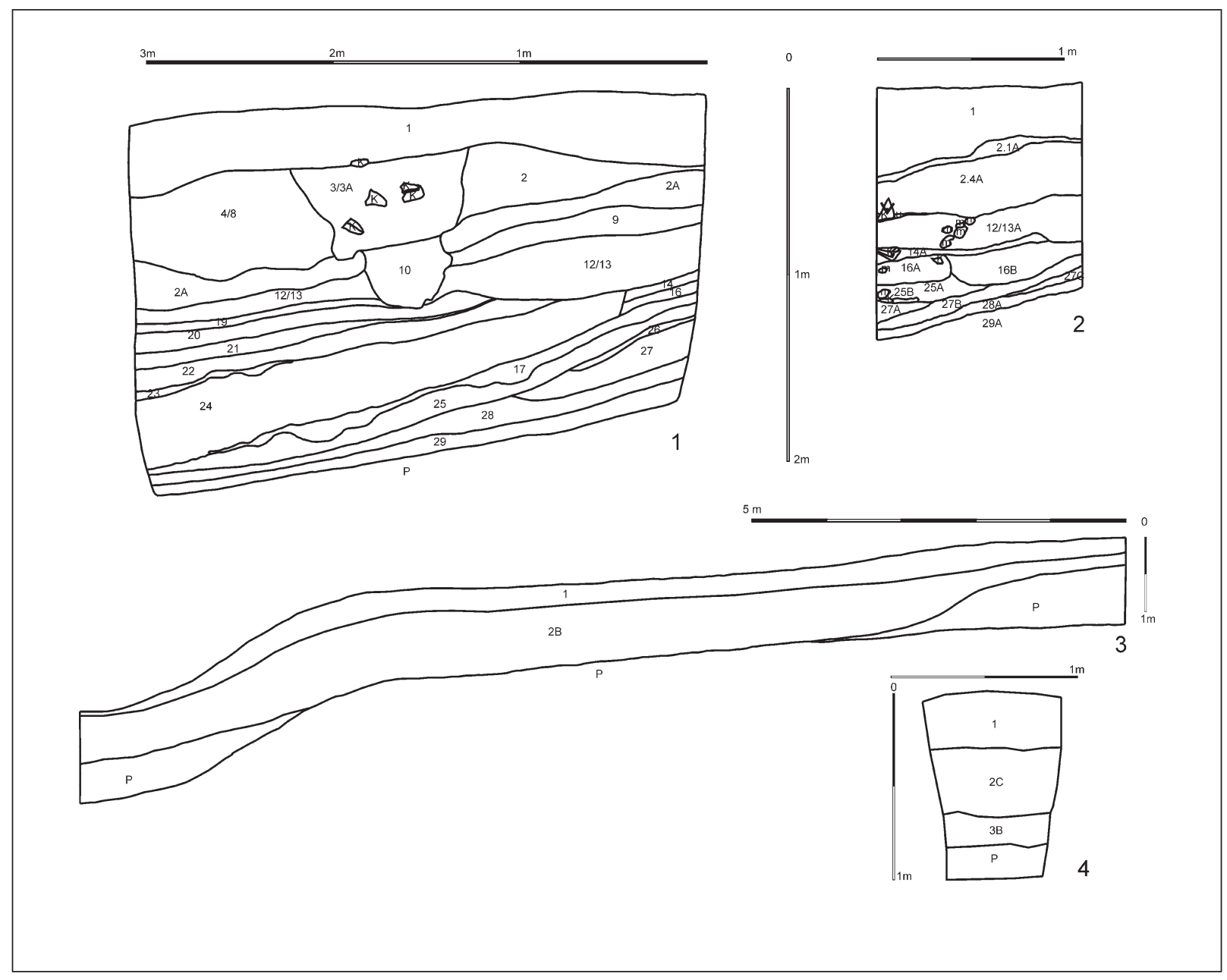

Obr. 2. Lokalita: Kežmarok, poloha Jeruzalemský vrch (okr. Kežmarok) Výkres: Profily rezov a archeologických sond realizovaných v rokoch 2000, 2013, 2016 (kresba M. Kučerová).

1 - Jeruzalemský vrch, hotel Štart, výskum 2013 (obr. 1, poloha 2), sonda III, severný profil; 2 - Jeruzalemský vrch, hotel Štart, výskum 2000 (obr. 1, poloha 2), sonda II, severný profil; 3 - Jeruzalemský vrch, plynová ryha pod hotelom Štart, výskum 2000 (obr. 1, poloha 3), severný profil výkopu (kolmý rez terasou); 4 - Jeruzalemský vrch, medzi zjazdovkami, SV od hotela Štart, výskum 2016 (obr. 1, poloha 4), severný profil výkopu s nálezom nádoby.

Legenda: 1 - humusovitá vrstva; 2 - drobivá sivá až svetlohnedá ílovito piesčitá vrstva; $2 \mathrm{~A}$ - mäkká svetlo sivohnedá ílovito piesčitá vrstva; 3/3A - svetlo sivohnedá ílovitá hlina s prímesou pieskovcových kameňov ; 4/8 - drobivá stredne hnedá ílovito piesčitá vrstva; 9 - mäkká, svetlo sivohnedá až oranžovohnedá ílovitá hlina; 10 - mäkká svetlohnedá ílovito piesčitá vrstva; 12/13 - drobivá až sypká svetlo sivohnedá ílovito piesčitá vrstva; 14 - tuhá, tmavosivá ílovitá vrstva s uhlíkmi; 16 - pevná, sivohnedá, piesčitá hlina (pravdepodobne premiešaná vrstva 14 a 17); 17 - drobivá až sypká svetložltá ílovito piesčitá vrstva s uhlíkmi a zvieracími kost̉ami; 19 - sypká, svetlo sivohnedá ílovito piesčitá vrstva; 20 - súdržná, mäkká, stredne hnedá ílovito piesčitá vrstva s inklúziami žltého ílu; 21 - drobivá, tmavo hnedá ílovito piesčitá vrstva s ojedinelou prímesou pieskovcových kameňov; 22 - tuhá sivá hlinitá vrstva; 23 - pevná, svetlo žltá piesčitá hlina; 24 - tuhá, tmavosivá až hnedá hlina; 25 - drobivá, červenohnedá ílovito piesčitá vrstva; 26 - tuhá, svetlo sivá hlina; 27 - pevná, hnedá až červenohnedá piesčitá hlina s prímesou uhlíkov a do červena prepálených kameňov; 28 - tuhá, sivá hlina s ojedinelým výskytom uhlíkov a pieskovcových kameňov; 29 - tuhá, tmavo hnedá hlina; 2.1.A - drobivá, sivočervená hlina s mazanicou a uhlíkmi; 2.4.A - drobivá, sivohnedá hlinitá vrstva; 12/13A - súdržná, mäkká, sivočierna hlina s prímesou mazanice; 14A - kompaktná, svetlosivá ílovitá vrstva s početnou prímesou mazanice a uhlíkov; 16A - hnedá, súdržná hlina s výraznou prímesou uhlíkov, mazanice a pieskovcových kameňov; 16B - sivo čierna, súdržná hlinitá vrstva; 25A - sivo červeno hnedá, pevná hlinitá vrstva s ojedinelou prímesou mazanice; 25B - sivá, pevná ílovitá vrstva; 27A - sivo červeno hnedá, pevná hlinitá vrstva; 27B - prepálená, pevná, hnedočervená ílovitá vrstva; 27C - pevná, prepálená, červenohnedá ílovitá vrstva; 28A - tuhá, sivá ílovitá vrstva s prímesou uhlíkov; 29A - tuhá, hnedá až hrdzavo hnedá ílovitá vrstva; $2 \mathrm{~B}$ - tmavohnedá hlinitá vrstva s prímesou uhlíkov; 2C - súdržná tmavosivá ílovito hlinitá vrstva; 3B - tuhá sivá vrstva zvetraného pieskovca, drobné úlomky zlepené ílom; P - intaktné podložie (prevažne zvetraný pieskovec); K - kameň; m - mazanica; u - uhlíky. 
Sondážne výskumy sa dotkli predovšetkým miest, kde boli povrchovým prieskumom zistené významné koncentrácie nálezov. Rozsahom najväčší výskum (v rokoch 1998, 2000, 2013; Giertlová 1998a; 2000; Giertlová/Mihok 2001, 75, 76; Giertlová/Soják/Wavrek 2000, 71, 72; Kučerová 2017) sa sústredil na zalesnenú terasu severne od hotela Štart (obr. 1, poloha 2). Celkovo tu bolo skúmaných pät na seba nadväzujúcich archeologických sond, pričom sa podarilo získat’ priečny rez terasou. Podstatnú čast̉ rezu predstavujú severné profily sond II/2000 a III/2013 (obr. 2). Viacnásobný sled vrstiev ukazuje, že osídlenie prešlo dlhšie trvajúcim vývojom. V bezprostrednej blízkosti sa nachádza lyžiarsky svah. Pri jeho úprave v roku 1974 zaznamenal L. Kiefer vel'ké množstvo nálezov v odstraňovanej zemine. Ak vezmeme do úvahy zmienky o tzv. Kolumbáriu na východnom svahu Jeruzalemského vrchu (Greisiger 1890, 56-58), označeného tak pre vel'ký počet nálezov keramiky, kostí a uhlíkov, potom je pravdepodobné, že skúmaná poloha nad hotelom Štart je okrajovou častou tzv. Kolumbária.

Okolie amfiteátra je do vel'kej miery zdevastované t’ažbou kameňa a stavebnou činnostou, čo potvrdila aj na tomto mieste uskutočnená sondáž (obr. 1, poloha 1; Kučerová 2017).

Zaujímavé sú polohy na terasách nachádzajúcich sa na južnom svahu Zámockého kopca nad ulicou Pod lesom. Pôvodne orané záhumienky postupne ustupujú individuálnej bytovej zástavbe. Na každej $\mathrm{z}$ oraných terás bolo možné sledovat $\mathrm{v}$ ich okrajových častiach výrazne do tmava sfarbené plochy, na ktorých sa koncentrovali nálezy - keramika, uhlíky, zvieracie kosti. Aj tu sa skúmali dve menšie sondy (obr. 1, polohy 5, 6), v ktorých sa výrazne rysovali časti objektov, zahíbených do podložia v híbke 0,4-0,6 m. Prekrývala ich ornica obsahujúca vyššie zmienený nálezový materiál (Giertlová 1998b; Giertlová/Soják/ Wavrek 2000, 72).

\section{CHARAKTERISTIKA MATERIÁLU}

Z rôznych polôh z Jeruzalemského vrchu pochádza bohatý, aj ked zväčša len fragmentárny keramický materiál. Vel'kú čast̉ tvoria doteraz nespracované zbery L. Kiefera, ako aj staršie zbery M. Greisigera, I. Spöttla, J. A. Heftyho (Baráthová a i. 2013, 42-45). Tieto nálezy sú uložené v Múzeu v Kežmarku a v Podtatranskom múzeu v Poprade. Čiastočne publikované a spracované sú predovšetkým novšie archeologické výskumy (Giertlová/Mihok 2001, 75, 76; Giertlová/Soják/Wavrek 2000, 71, 72; Kučerová 2013, 6, 7; 2017; Soják 1998, 148, 149).

Ide (až na ojedinelé prípady) o v ruke robenú, zväčša úžitkovú keramiku (súdkovité nádoby, hrnce, zásobnice, amfory), vypálenú v redukčnom prostredí. Vo vel'kej miere je keramika z Jeruzalemského vrchu nekvalitná, hrubo opracovaná, drobivá, často zle vypálená. Množstvo fragmentov obsahuje výraznú prímes štrku a piesku, má drsný až krupicovitý povrch. Farebne prevláda čierna, tmavo hnedá a iné kombinácie tmavších farieb, no zastúpené sú aj svetlejšie farby ako svetlohnedá, či dočervena a oranžova ladené farby. Charakteristikou sa zhoduje s keramikou z iných známych nálezísk púchovskej kultúry zo Spiša (Soják 1998, 148; Soják/Fecko 2012, 249; a iné).

Prevahu majú nádoby s ústím zatiahnutým dovnútra alebo esovito profilované nádoby. V prípade nádob so zatiahnutým ústím ide o súdkovité hrnce s jednoducho zaobleným okrajom (tab. II: 3; Giertlovál Mihok 2001, obr. 49: 10,15), niekedy so zvýraznenou okrajovou lištou, častejšie však s okrajom odsadeným žliabkom, prípadne so zosilneným okrajom (Giertlová/Soják/Wavrek 2000, obr. 45: 1). Okrem hrncov patria k nádobám so zatiahnutým okrajom aj súdkovité šálky (Giertlová/Mihok 2001, obr. 49: 9), prípadne kónické misy (tab. II: 12). K jemnejším stolovým výrobkom patria fragmenty váz, džbánov či miniatúrne vázičky, pri ktorých sa stretávame aj s plynulou esovitou profiláciou (tab. II: 4, 14; Giertlová/Mihok 2001, obr. 49: 6). Častejšie však vystupujú dvojkónické tvary s výraznejším lomom vydutia (tab. II: 11; Giertlová/Mihok 2001, obr. 49: 8), posunutým nie ojedinele do jeho spodnej časti, s kónicky sa zužujúcou hornou častou (tab. II: 6, 13) a s von vyhnutým okrajom (tab. II: 5, 10; III: 4). Sporadicky sa vyskytli tvary s kónicky sa zužujúcim hrdlom, zosilneným a len mierne von vyhnutým okrajom (Giertlová/Soják/Wavrek 2000, obr. 45: 5). V nálezoch sa objavujú aj fragmenty zásobníc s esovitou profiláciou (tab. II: 7; Giertlová/Mihok 2001, obr. 49: 16), ojedinele zásobnice so zosilneným a rovno zrezaným okrajom s okružím (GiertloválSoják/ Wavrek 2000, obr. 45: 1, prvý v poradí). Vzácnejšie sú aj zlomky grafitových zvislo hrebeňovaných sitúl. 


\section{Zdobená keramika}

Z doteraz analyzovaného súboru fragmentov keramiky z Jeruzalemského vrchu je zdobených menej ako $10 \%$ z celkového počtu fragmentov. Na keramike sa vyskytujú viaceré výzdobné prvky a motívy. Objavuje sa plastická výzdoba (plastické výčnelky v podobe zvieracích hlavičiek, jazykovité výčnelky, plastická pretláčaná lišta, hrotité výčnelky), vhlibená (ryté línie, žliabky, vpichy, jamky, zdobenie hrebeňom), ojedinele povrchová (mal'ovanie, leštenie, tuhovanie) výzdoba.

Za dôležitý výzdobný prvok v náplni materiálnej kultúry považujeme dvojicu zvieracích hlavičiek na ohybe pásikového ucha. V prípade exemplárov z Jeruzalemského vrchu bola táto výzdoba uplatnená na džbánoch a šálkach. Unikátny je nález pokrievky, kde je ako držadlo použitý motív zvieracej hlavičky (tab. III: 3). Zoomorfné aplikácie z Jeruzalemského vrchu sa objavujú v zberových materiáloch už v 19. stor. (tab. III: 3-5). V roku 2013 pribudli z výskumu tri zlomky takejto keramiky. Dva majú čiernu farbu a pravdepodobne pochádzajú z džbánu (tab. III: 2; V: 4). Jeden z exemplárov má zachované obidva výčnelky v podobe štylizovaných zvieracích hlavičiek (tab. IV). Povrch je leštený. Druhý z opisovaných fragmentov mal pôvodne dva rohaté výčnelky v podobe zrezaných kuželov modelovaných z okraja ucha (tab. III: 2). Povrch má drsný. Ďalší fragment pravdepodobne s rovnakým stvárnením výčnelkov, má nie velmi častú kožovitú úpravu povrchu s perforáciou v mieste napojenia výčnelku na okraj nádoby (tab. III: 1 ; V: 2).

Keramika s aplikáciou býčích hláv či rohatých výčnelkov na ohybe širokých pásikových úch je známa z viacerých lokalít na Spiši z povodia rieky Hornád a Poprad, ale aj z Liptova (Pieta 1982, 93-95; 2000, 339; 2003, 150) a z Horehronia (Benediková/Kovár 2007, 157, obr. 12: 1, 2; Kvietok 2017, 19, obr. 5). Tvarovo podobné kusy pochádzajú z Novej Lesnej, zo Zelenej hory v iciach, zo Spišského Hrhova, z Jánoviec-Machaloviec, polohy Hradisko, zo Žehry, Spišského hradu a z Novej Lesnej, Hliníka (Miroššayová 1992, 134, Spišský Hrhov najnovšie Soják/Fecko 2012, 256, 259, obr. 8: 4a, 4b, 5a, 5b). Použitý výzdobný motív je domácemu kultúrnemu prostrediu cudzí (Miroššayová 1992, 134; 1999, 162; Novotný/Novotná/Kovalč́k 1991, 41; Pieta 2003, 150). Tento výrazný prvok naznačuje vplyvy z juhu, z východoalpskej oblasti (Tankó 2005, 157), ktoré koncom doby halštatskej a začiatkom doby laténskej prenikajú d’aleko na sever (Pieta 2003, 150). Môžeme si položit otázku, či tieto vplyvy boli určované obchodným stykom alebo len kontaktom medzi vtedajšími horskými neskorohalštatskými spoločenstvami. Pôvod a prenikanie týchto vplyvov do strednej Európy sledoval vo svojej práci K. Tankó (2005), pričom na základe celých tvarov alebo fragmentov tejto keramiky z lokalít v strednej Európe - v Madarsku, Slovinsku a východnej časti Rakúska vypracoval základnú typológiu a chronológiu (Tankó 2005, 154-158). V práci uvádza aj lokality z juhozápadného a z juhovýchodného Slovenska (Tankó 2005, obr. 3). Pre nálezy zo Spiša, Liptova, či Horehronia zatial' nebola vypracovaná presná chronológia, najmä pre chýbajúce uzavreté nálezové celky (Miroššayová 1984, 28; 1992, 134). Všeobecne sa ich výskyt datuje od záveru doby halštatskej až do staršej doby laténskej (Miroššayová 1984, 36; Pieta 1982, 93, 94). Zvieracie hlavičky z Jeruzalemského vrchu, vzhladom na známy nálezový materiál z lokality, predbežne datujeme len rámcovo do predpúchovského horizontu.

Medzi d’alšie výzdobné prvky na keramike z Jeruzalemského vrchu, ako už bolo spomínané vyššie patrí rytá výzdoba, žliabky, plastická lišta, hrotité výčnelky, vpichy, prstami vtláčaná výzdoba, hrebeňom zdobená keramika, ojedinelo sa vyskytuje malovaná keramika (tab. IV: 4).

Častým dekoračným prvkom z Jeruzalemského vrchu je rytá výzdoba (tab. I: 7). Objavuje sa predovšetkým na zlomkoch váz a džbánov, kde sa sústreduje na pleciach nádoby (tab. I: 7; GiertloválSoják/ Wavrek 2000, obr. 45: 3, 5), a to v charakteristickom motíve dvoch, prípadne viacerých horizontálnych rytých línií, pod ktorými sú zväzky zvislých alebo šikmých rytých línií. Ohraničenie horizontálnymi líniami bolo zatial' zistené len v hornej časti výzdoby. Väčšina fragmentov nie je zachovaná natolko, aby bolo možné otázku vymedzenia ornamentu na ploche vydutia nádoby riešit. Zo spišských lokalít je možné nájst podobnú výzdobu napríklad na Spišskom hrade (kataster Žehry) a v Hrabušiciach, na Zelenej hore (Roth 2003, tab. 72; aj nepublikovaný nákres M. Slivku z Hrabušíc, Zelenej hory). Jemne rytá výzdoba sa objavuje na keramike neskorohalštatského a predpúchovského stupňa (Benediková 2004, tab. IV). Vyššie opísaná rytá výzdoba neohraničená v spodnej časti horizontálnymi líniami charakterizuje skôr obdobie púchovskej kultúry neskorej doby laténskej a objavuje sa opät v podobe tenkých rytých línií aj na začiatku doby rímskej (stupeň B1a; Pieta 1982, 90). V súbore keramiky sa vyskytuje ojedinele aj rytá výzdoba viazaná k mladším tvarom keramiky (tab. I: 4; Giertlová/Soják/Wavrek 2000, obr. 45: 4), a to v podobe jednotlivých súbežných línií, alebo zväzkov oblúkovitých línií, ktorá sa objavuje na hrncovitých nádobách v závere neskorolaténskeho obdobia a pretrváva do staršej doby rímskej. 
Žliabkovaná výzdoba, ktorá zažila renesanciu na konci strednej a v neskorej dobe laténskej (Pieta 1982, 89), sa vyskytla aj v mapovanom súbore keramiky prevažne na zlomkoch s čiernym lešteným povrchom pochádzajúcich z džbánov, prípadne amfor (zlomok ucha so žliabkovanou výzdobou; Giertlová/Mihok 2001, obr. 49: 3; Giertlová/Soják/Wavrek 2000, obr. 45: 7).

Výzdoba v podobe plastických líšt sa nachádza spravidla bud' pod okrajom, alebo v hornej, bližšie neurčitel’nej časti tela nádoby. Plastické lišty sú pretláčané (tab. I: 10, 12; IV: 5, 6) a vedené horizontálne. Zo zlomkovito zachovaného materiálu však nie je možné určit, či boli lišty vedené aj po celom obvode nádoby. Pokial' bolo možné identifikovat’ tvar nádoby, zväčša išlo o hrnce so zatiahnutým ústím (tab. IV: 5). Istú podobnost' s plastickými lištami z Jeruzalemského vrchu vykazujú aj nálezy z Novej Lesnej (Pieta 2003, obr. 1, 150) a v širšom kontexte aj z Detvy, Kalamárky, a z obce Kvašov, Ostrá hora (Benediková 2006, tab. LXXI: 2-6; Šalkovský 2002, obr. 4). Zo starších zberov poznáme fragment okraja hrnca s výrazne zatiahnutým ústím, a visiacim plastickým poloblúkom pod zvýraznenou okrajovou lištou, ktorý je možné zaradit do predpúchovského horizontu (Pieta 1982, 88).

Plastické výčnelky (tab. I: 11; IV: 7, 9, 11, 12) sa nachádzajú pod okrajom nádob, menej často na vydutí (tab. IV: 9). Výčnelky sú bud' jazykovité, alebo hrotité. Tvarovo ide zväčša o väčšie súdkovité nádoby s dovnútra zatiahnutým okrajom. Farebne variujú od čiernej až po svetlú lososovú. Výzdoba z nádoby s dvoma výčnelkami sa našla aj na spišskej lokalite - Nová Lesná, Hliník, kde je nálezový súbor ako celok označený ako „predpúchovská keramika“ (Pieta 2003, obr. 1).

Vtláčaná výzdoba $\mathrm{v}$ podobe jednotlivých jamiek, resp. dvojíc či radu jamiek umiestnených pod okrajom nádoby s dovnútra zatiahnutým ústím sa vyskytla na viacerých fragmentoch (tab. IV: 1, 2, 8). Aj ked' uvedený spôsob výzdoby sa objavuje v celom okruhu púchovskej kultúry aj v neskorších časových obdobiach (Pieta 1982, 88), s výzdobou prstovými jamkami umiestnenými pod zatiahnutým okrajom nádob sa stretávame už v predpúchovskom horizonte (Soják/Fecko 2012, 255, obr. 5: 11).

Výzdoba v podobe trojuholníkovitých vpichov na pleciach nádoby pod žliabkom odsadeným a do vnútra zatiahnutým okrajom (Giertlová/Soják/Wavrek 2000, obr. 45: 2,6) charakterizuje nálezy zo záveru neskorolaténskeho obdobia, pričom so samotným výzdobným motívom sa možno stretnút aj na hrncovitých nádobách v staršej dobe rímskej (Pieta 1982, 88, 89).

V starších zberových nálezoch z Jeruzalemského vrchu má svoje zastúpenie keramika zdobená hrebeňom (Roth 2003, tab. 28: 5; 29: 2; 21: 4; 20: 1). Tvarovo najčastejšie boli zastúpené situly, prípadne väčšie nádoby (hrnce). Chronologicky sa hrebeňom zdobená keramika na rôznych typoch nádob vyskytuje od predpúchovského stupňa až do neskorej doby laténskej (Pieta 1982, 88). Zo spišských lokalít má najväčšie zastúpenie keramiky so zvislým hrebeňovaním na Hradisku v Jánovciach-Machalovciach (Pieta 2003, 142).

Z výskumu v roku 2013 pochádza drobný kus z vydutia malovanej, na hrnčiarskom kruhu vyrobenej nádoby (tab. V: 4). Je tehlovej farby s bielou linkou. Tento typ keramiky sa objavuje niekedy koncom strednej doby laténskej na strednom Dunaji a rýchlo sa rozšíril aj na severnú a východnú perifériu keltskej civilizácie, na územie púchovskej kultúry (Pieta 1982, 118-122; 2008, 169-172). Lokálne sa udržal (tyniecka skupina v Pol'sku) až do prelomu letopočtu (Pieta 1982, 118-122; 2008, 172). Na Spiši sa našlo najviac malovanej keramiky na hradisku v Jánovciach-Machalovciach (Novotný/Novotná/Kovalč́k 1991, 16; Pieta 1982, 119; Roth 2003, 63).

Prasleny zdobené okrúhlymi vpichmi usporiadanými do tvaru trojuholníkov (tab. V: 5), alebo zvislými žliabkami (tab. V: 3) dopĺńajú škálu výzdobných prvkov použitých na výrobkoch z keramiky. Nepredstavujú však chronologicky preukazný prvok.

\section{ZÁVER}

Napriek tomu, že v zlomkovito zachovanom súbore sa nedajú vymedzit jednotlivé stupne v celom rozsahu ich keramickej náplne, predsa je možné na základe zastúpených tvarov a výzdoby vyčlenił charakteristické nálezy, ktoré môžu definovat zatial' rozpoznané základné etapy osídlenia lokality.

Výzdoba na ohybe ušiek (a pokrievke) nádob v podobe rohovitých výčnelkov, resp. štylizovaných zvieracích hlavičiek už bola podrobnejšie analyzovaná v predchádzajúcej časti. Na základe doterajších poznatkov ju možno, zatial' len rámcovo, zaradit do predpúchovského stupňa. Pre staršie datovanie nenachádzame dostatočnú oporu $\mathrm{v}$ ostatnom dosial’ spracovanom nálezovom materiáli. Medzi nálezmi sa pomerne často vyskytujú na halštatskú, resp. včasnolaténsku keramiku odkazujúce tvary, s profilá- 
ciou s nízko položeným, ostrejšie lomeným vydutím a s kónicky sa zužujúcou hornou častou ukončenou von vyhnutým okrajom. Objavuje sa aj rytá výzdoba, pretláčané plastické lišty a plastické výčnelky na rôznych častiach nádob, no paralely k nim či odôvodnenie výskytu nachádzame aj priamo v náplni predpúchovského stupňa a púchovskej kultúry samotnej. Nález diadému typu Istebné neposkytol v tejto veci další oporný bod, ked’že podla záverov $M$. Sojáka $(2015,156,157)$ nie je vylúčené, že bol použitý v mladšom kultúrnom prostredí, než do akého je horizont s nálezmi tohto typu ako celok datovaný.

Ku keramike z predpúchovského stupňa môžeme zaradit aj vel'ké zásobnice s esovitou profiláciou (Pieta 1982, 99, tab. XXI: 9, 10) a hrnce so zatiahnutým ústím, a visiacim plastickým poloblúkom pod zvýraznenou okrajovou lištou (Pieta 1982, 88), možno aj niektoré fragmenty s jemnou rytou výzdobou na pleciach nádoby pod kónicky sa zužujúcim hrdlom a zosilneným, mierne vyhnutým okrajom. V súvislosti s osídlením v predpúchovskom stupni je potrebné pripomenút aj nález perly cievkovitého tvaru (Pieta 1982, 58) a zlomku skleného náramku typu 13 (Březinová 2017, 47; Pieta 1982, 52), ktoré sú uložené v Múzeu v Kežmarku.

Výrazné sú doklady osídlenia v období vlastnej púchovskej kultúry počínajúc od záveru strednej doby laténskej (LTC2) a v celom období neskorej doby laténskej (LTD). Esovitá profilácia nádob, výskyt výraznejšie až lievikovito vytiahnutých okrajov nad kónicky sa zužujúcim hrdlom (Pieta 1982, 90, 92), hrnce so zatiahnutým ústím a zosilneným okrajom (Pieta 1982, 88) charakterizujú tento časový úsek osídlenia lokality. Predlohy k dvojkónickým nádobám s výraznejšie profilovaným lomom na maximálnom vydutí možno hladat aj v tomto období, a to v keramike vyrábanej na hrnčiarskom kruhu (Liptovská Sielnica-Liptovská Mara VII - hrnčiarska pec 1; Pieta 1982, tab. XXXIV: 17, 19). Podobne menšia vázovitá nádoba objavená v roku 2016 (tab. III: 6) pripomína tvarovo ostro profilované vázy z portfólia na hrnčiarskom kruhu vyrábanej keramiky neskorej doby laténskej z celého úseku LTD (Pieta 1982, 92, taf. XXXIV: 1-3). Profilácia jej spodnej časti však vyvoláva otázku, či skôr nezodpovedá tvarom inšpirovaným ostro lomenými misami (terinami) staršej doby rímskej. Je však zrejmé, že nádoba patrí ku keramickému inventáru púchovskej kultúry (Kučerová 2016, 22).

Najmladšie nálezy z lokality možno predbežne podla výzdoby v podobe oblúkovitého zväzku rýh či trojuholníkovitých vpichov pod okrajom datovat do záveru neskorej doby laténskej až do začiatku staršej doby rímskej (B1a).

Na základe doterajších poznatkov môžeme uvažovat’ aj o sídliskovej štruktúre lokality. Opevnená poloha na Jeruzalemskom vrchu s pôvodne viacnásobným prstencom opevnenia podla všetkého nezaberala viac ako 1,5-2,0 ha, pričom „,akropola“ samotná nemala priemer väčší ako $50 \mathrm{~m}$. Opevnenie slúžilo pravdepodobne ako útočisko pre obyvatel'stvo žijúce v jeho bezprostrednej blízkosti. Osídlenie sa rozkladalo v celom okolí hradiska. Možno ho charakterizovat', azda okrem hustejšie obývaného a dnes už zničeného predhradia na východnej strane, označovaného v historickej literatúre aj ako Kolumbárium (Greisiger 1890), ako osídlenie roztrúsené na prilahlých terasovito upravených svahoch. Takáto organizácia sídliska nebola v horskom teréne severnej časti Slovenska výnimočná a možno s ňou rátat zrejme už od začiatku strednej doby laténskej (Pieta 2008, 70).

Ajnapriek uvedeným záverom, ktoré môžeme vyvodit z doterajších poznatkov o lokalite, je výpoved ná hodnota materiálu bez komplexnejšieho prístupu a možnosti väčšieho odkryvu stále obmedzená. Ide však o problém, ktorý sa spája takmer so všetkými lokalitami osídlenými púchovskou kultúrou na Spiši. 

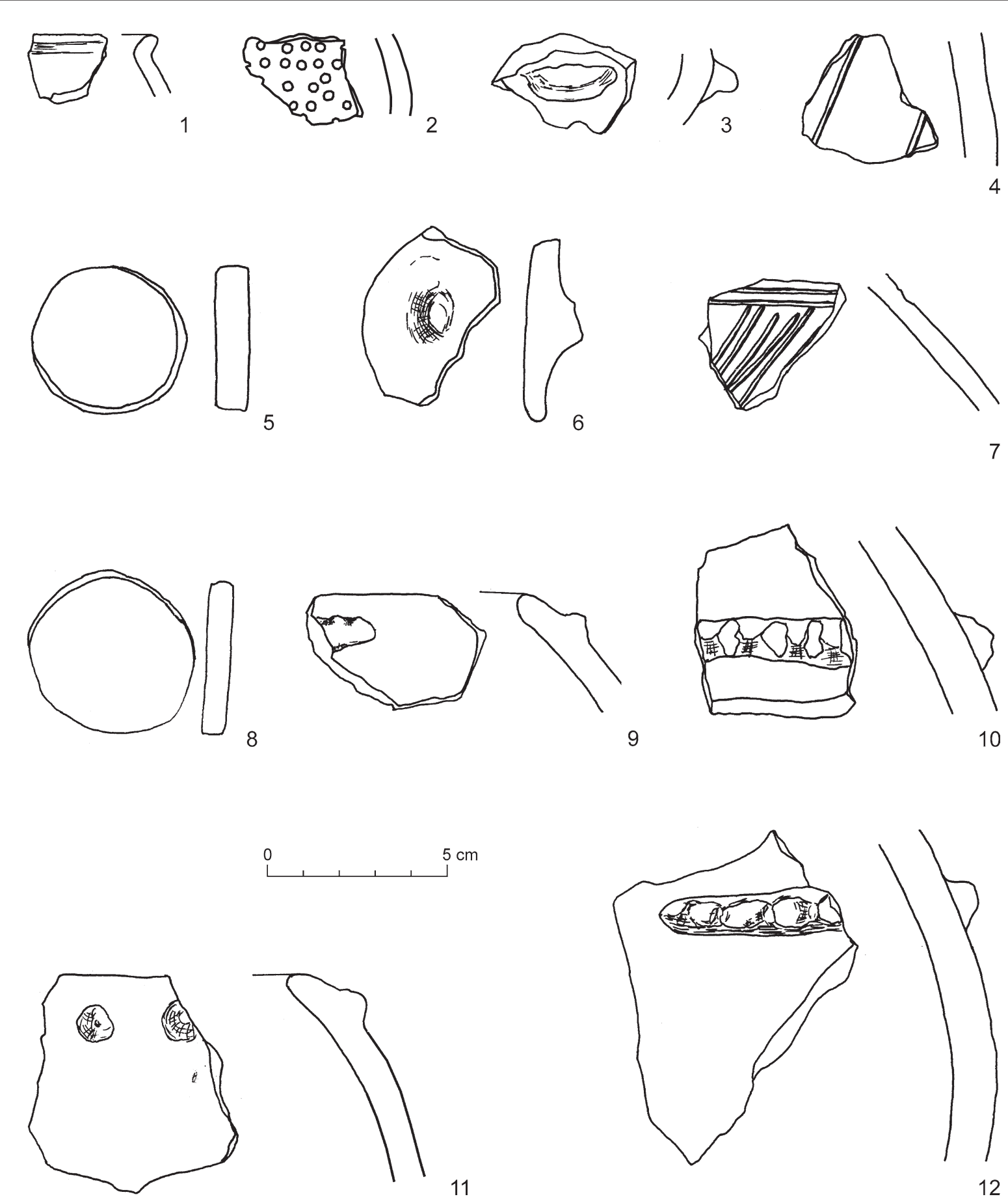


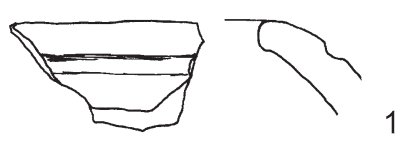

1

.
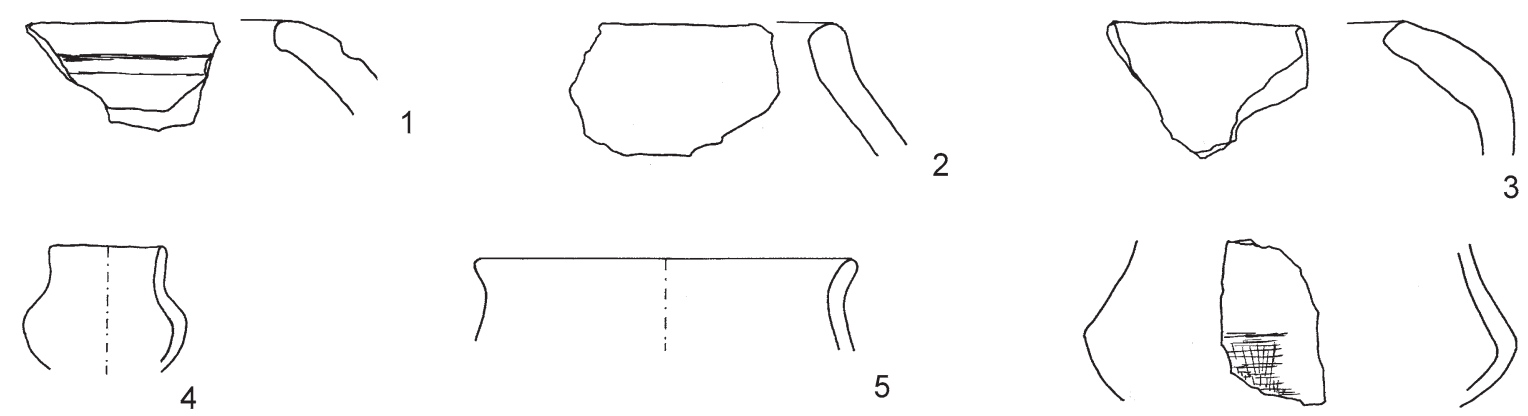

5
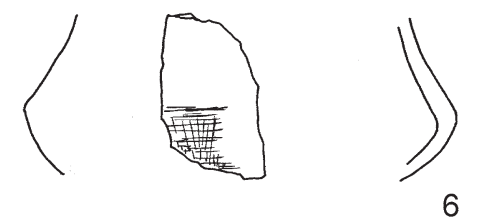

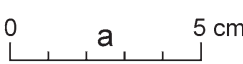
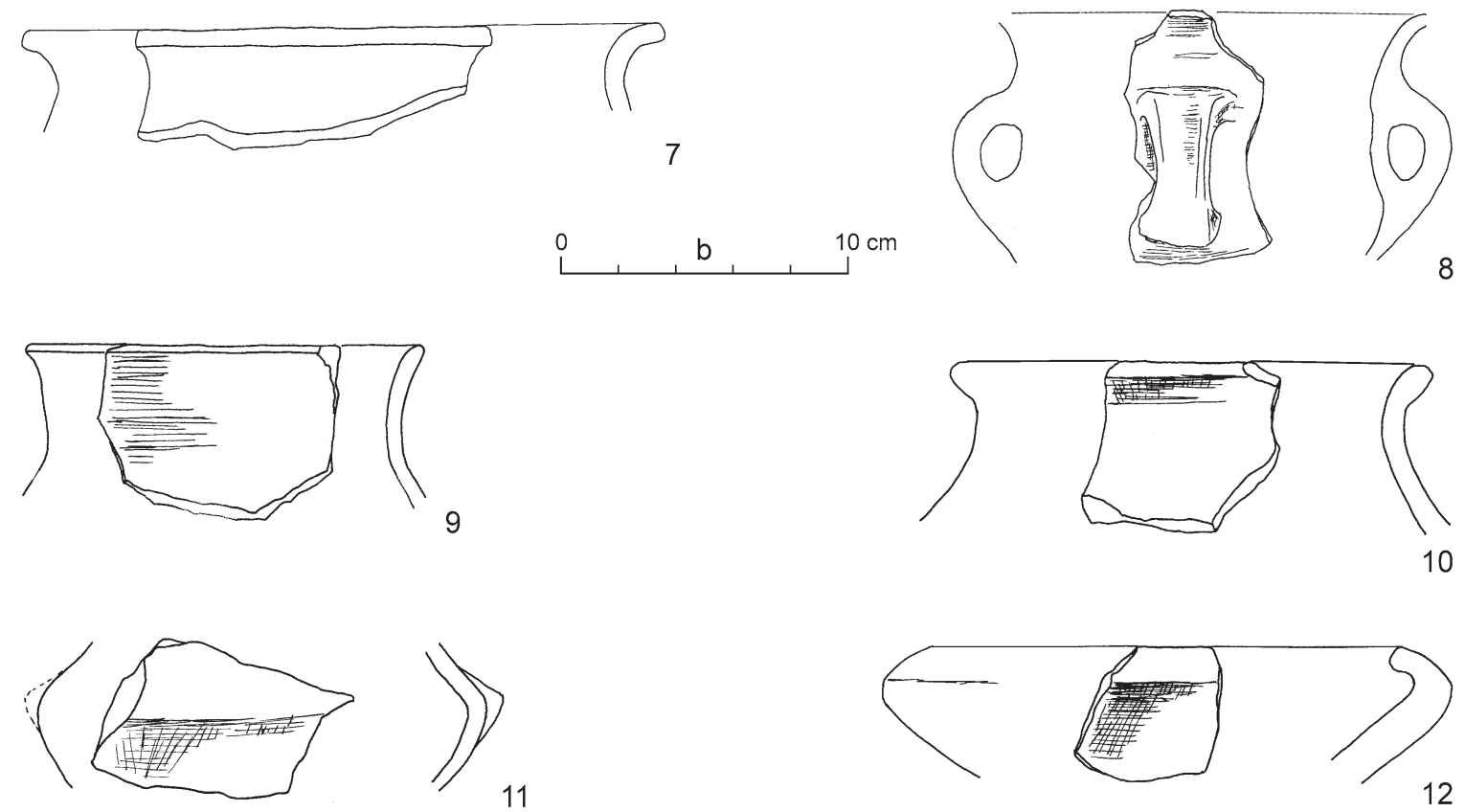

0
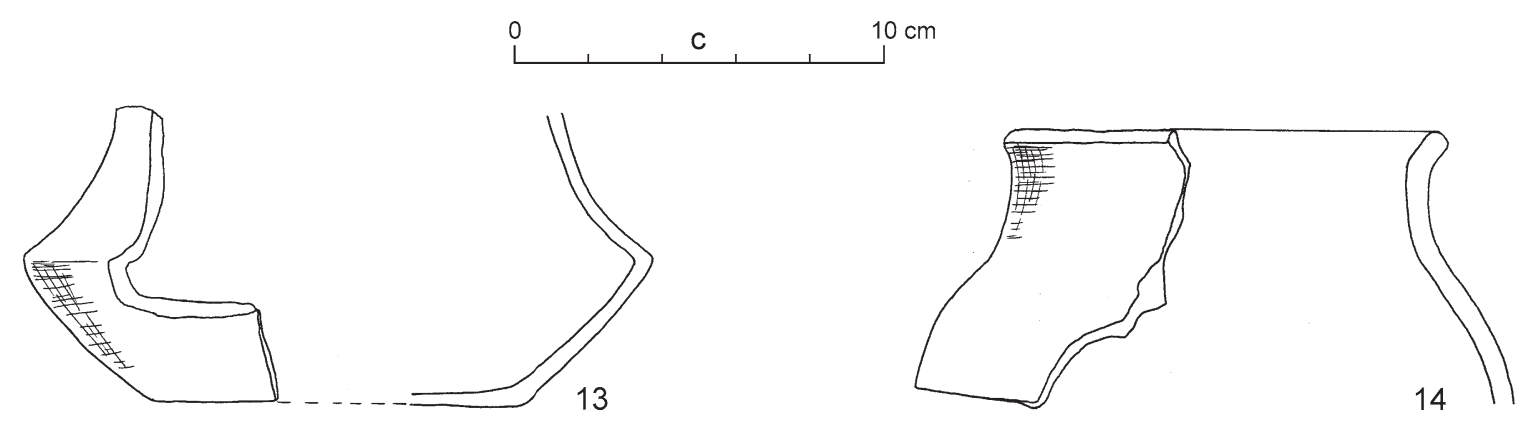

Tab. II. Kežmarok, Jeruzalemský vrch, poloha hotel Štart (okr. Kežmarok). Archeologický výskum v roku 2013. Výber nálezov. Mierka: a -1-6; b-7, 8; c-9-14 (kresba M. Kučerová). 

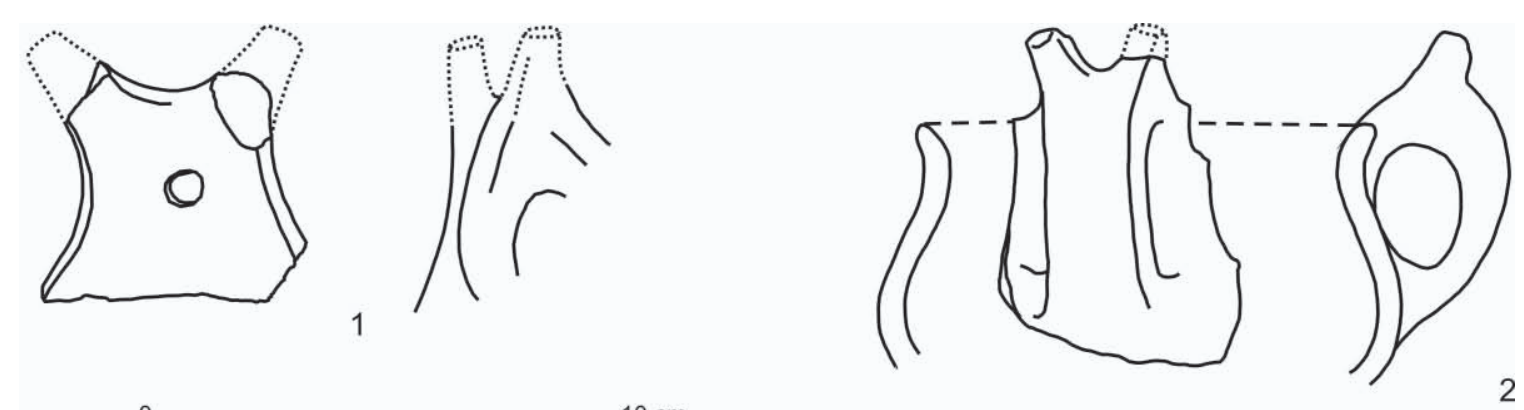

0

$10 \mathrm{~cm}$
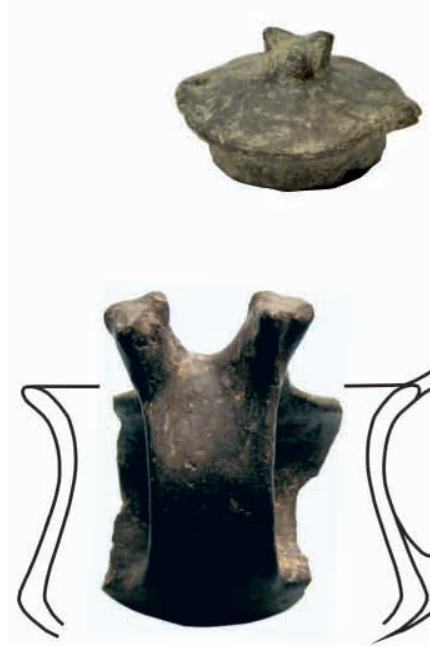

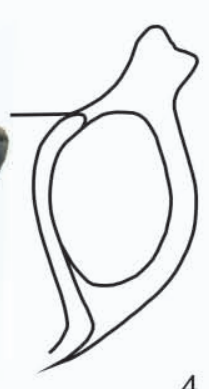

4
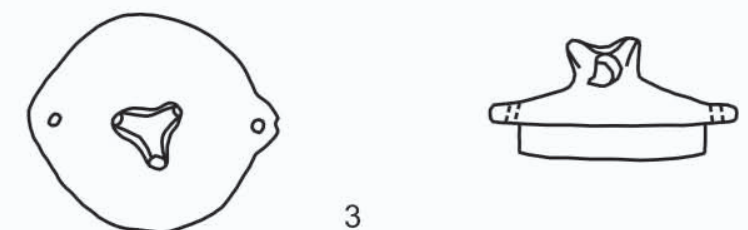

3

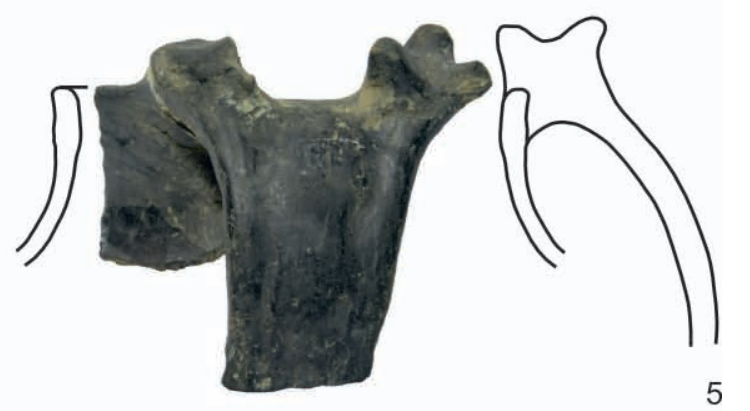

b $10 \mathrm{~cm}$

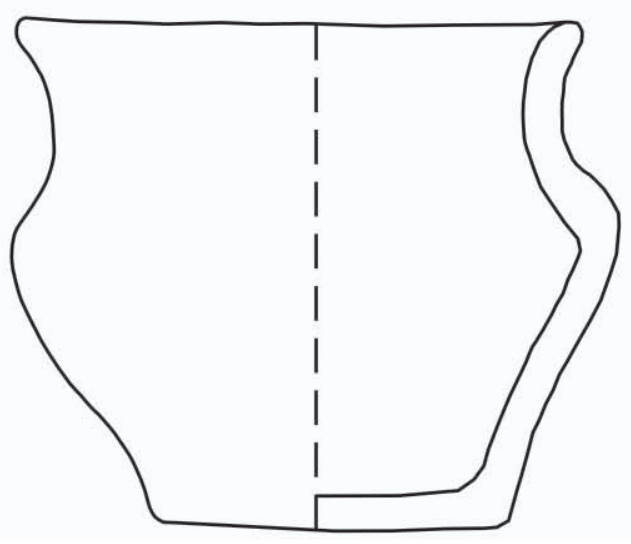

Tab. III. Kežmarok, Jeruzalemský vrch (okr. Kežmarok). Výber nálezov. 1, 2, 6 - poloha hotel Štart (archeologický výskum v roku 2013); 3-5 - nálezy zo zbierky M. Greisigera (Múzeum v Kežmarku). Mierka: a - 1, 2; b - 3-6 (kresba M. Kučerová, foto A. Námerová). 


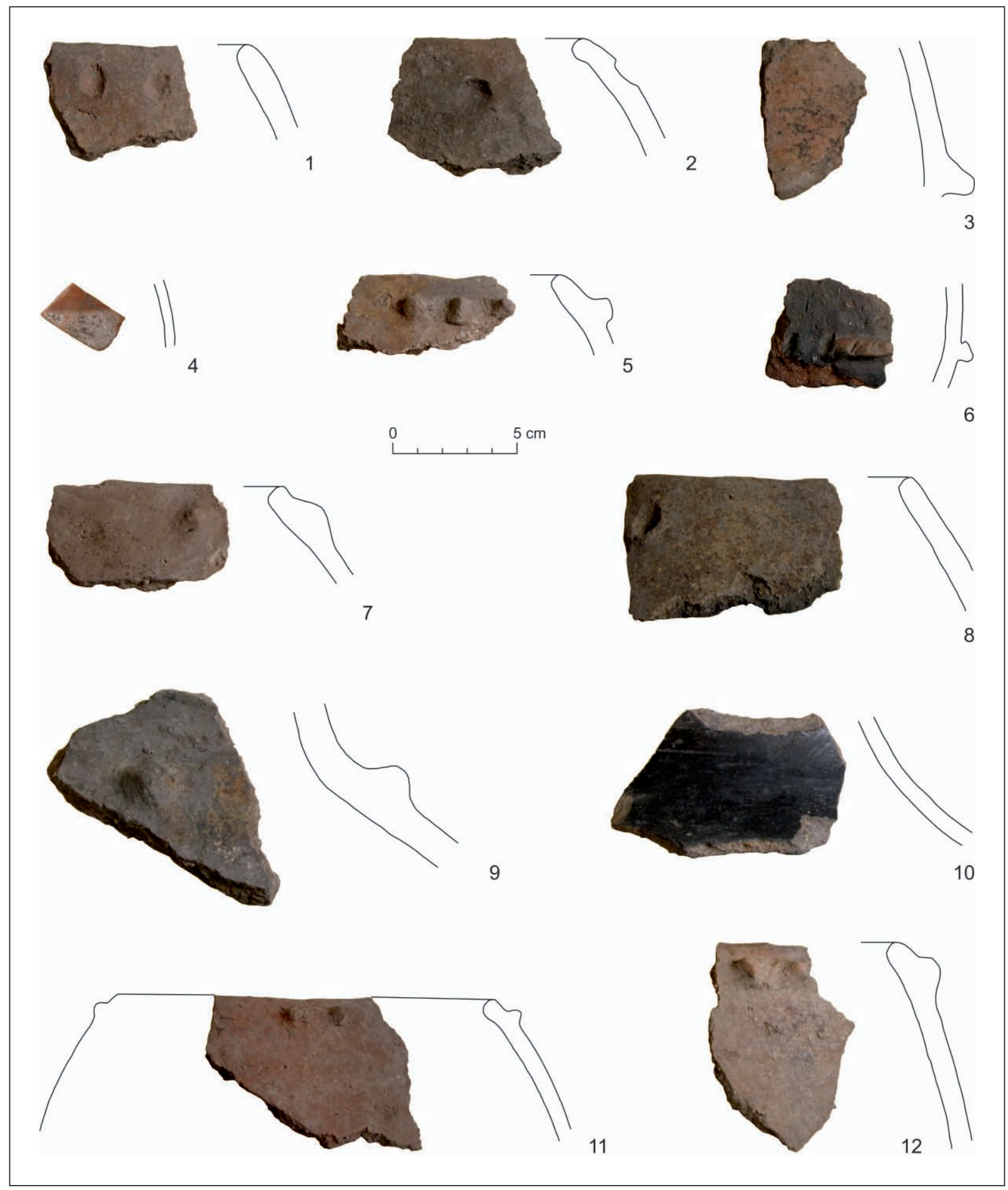

Tab. IV. Kežmarok, Jeruzalemský vrch, poloha hotel Štart (okr. Kežmarok). Archeologický výskum v roku 2013. Výber nálezov (kresba M. Kučerová, foto A. Námerová). 


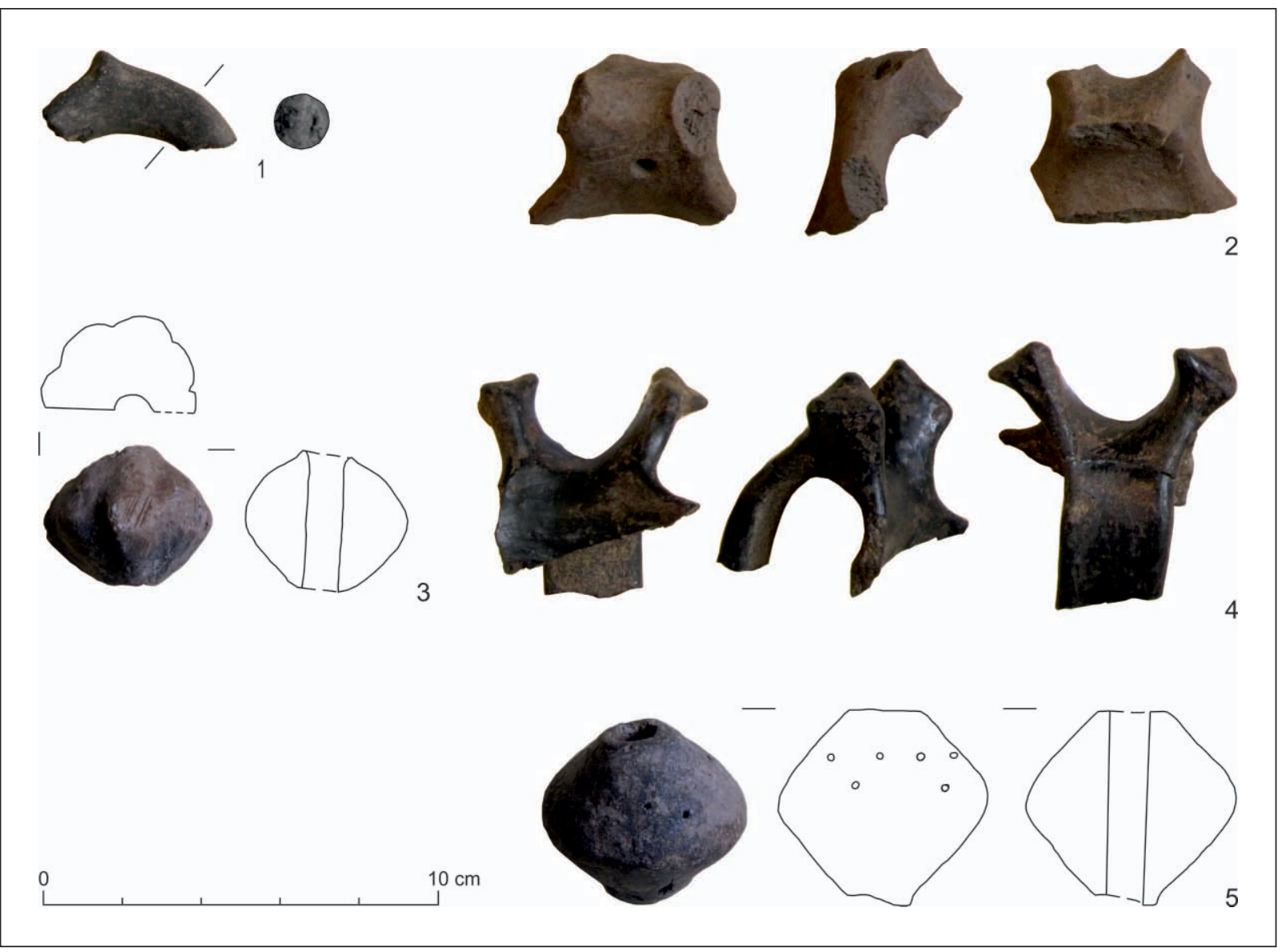

Tab. V. Kežmarok, Jeruzalemský vrch, poloha hotel Štart (okr. Kežmarok). Archeologický výskum v roku 2013. Výber nálezov (kresba M. Kučerová, foto A. Námerová). 


\section{LITERATÚRA}

Baráthová a i. 2013

Benediková 2004

Benediková 2006

Benediková/Kovár 2007

Bohus 1919

Březinová 2017

Giertlová $1998 a$

Giertlová $1998 b$

Giertlová 2000

Giertlová/Mihok 2001

Giertlová/Soják/Wavrek 2000

Greisiger 1890

Gross 1999

Hajts 1926

Hefty 1925

Kiefer 1974

Kučerová 2013

Kučerová 2016

Kučerová 2017

Kvietok 2017

Lipták 1934

Miroššayová 1984

Miroššayová 1992

Miroššayová 1999

Novotný/Novotná/Kovalčík 1991

Pieta 1982

Pieta 2000

Pieta 2003
N. Baráthová/K. Fábrová/M. Kučerová/V. Vráblik: História Kežmarku do polovice 18. storočia. Kežmarok 2013.

L. Benediková: Koniec doby halštatskej a začiatok doby laténskej v slovenských Karpatoch (na príklade lokality Istebné-Hrádok). In: J. Gancarski (ed.): Okres lateński i rzymski w Karpatach polskich. Materiaty z konferencji. Krosno 2004, 93-122. L. Benediková: Besiedlung der Westkarpaten und des nördlichen Teils der Ostkarpaten von der Hallstatt- bis zur Mittellatènezeit. Dizertačná práca (Archeologický ústav SAV). Nitra 2006. Nepublikované.

L. Benediková/B. Kovár: Einige Bemerkungen zu den Funden aus dem Burgwall Detva-Kalamárka. Východoslovenský pravek 8, 2007, 143-160.

G. Bohus: Historisch-geographische Beschreibung des in Oberungarn berühmten Zipser Landes. Kežmarok 1919.

G. Březinová: Keltské sklo z vybraných výšinných polôh na Slovensku. In: K. Harmadyová (zost.): Devín Veroniky Plachej. Zborník k životnému jubileu PhDr. V. Plachej. Bratislava 2017, 45-62.

M. Giertlová: Kežmarok-Jeruzalemský vrch. Výskumná dokumentácia 1/1998. Múzeum v Kežmarku. Kežmarok 1998. Nepublikované.

M. Giertlová: Kežmarok-Jeruzalemský vrch. Výskumná dokumentácia 2/1998. Múzeum v Kežmarku. Kežmarok 1998. Nepublikované.

M. Giertlová: Kežmarok-Jeruzalemský vrch. Výskumná dokumentácia 1/2000. Múzeum v Kežmarku. Kežmarok 2000. Nepublikované.

M. Giertlová/L. Mihok: Prieskum na lokalite Kežmarok-Jeruzalemský vrch. Archeologické výskumy a nálezy na Slovensku v roku 2000, 2001, 75, 76.

M. Giertlová/M. Soják/P. Wavrek: Prieskum na lokalite Jeruzalemský vrch. Archeologické výskumy a nálezy na Slovensku v roku 1998, 2000, 71, 72.

M. Greisiger: Kesmark in der Steinzeit. Karpathen-Post 11, 1890, 25, 26.

P. Gross: P. Gross: Vysvetlivky ku geologickej mape Popradskej kotliny, Hornádskej kotliny, Levočských vrchov, Spišsko-šarišského medzihoria, Bachurne a Šarišskej vrchoviny. Bratislava 1999.

B. Hajts: Beiträge zur Urgeschichte und Vorgeschichte der Zips. Turistik, Alpinismus, Wintersport 7, 1926, 19, 20.

J. A. Hefty: Wom Karpathenmuseum. Touristik, Alpinismus, Wintersport 6, 1925, $78,79$.

L. Kiefer: Nálezová správa o záchrannom archeologickom výskume za roky 1969/1973. Archeologický ústav SAV. Nitra 1974. Nepublikované.

M. Kučerová: Archeologický výskum na Jeruzalemskom vrchu v Kežmarku. Noviny Kežmarok 19, 2013, 6, 7.

M. Kučerová: Dokumentácia nálezu nádoby púchovskej kultúry z lokality Jeruzalemský vrch KN-C parc. č. 8639 v k. ú. Kežmarok. Výskumná dokumentácia 1/2016. Múzeum v Kežmarku. Kežmarok 2016. Nepublikované.

M. Kučerová: Kežmarok-Jeruzalemský vrch. Výskumná dokumentácia 6/2013, Múzeum v Kežmarku. Kežmarok 2017. Nepublikované.

M. Kvietok: Prvé výsledky archeologického výskumu v Brusne potešili a povzbudili. Čipkárske zvesti. Občasník obce Brusno 2, 2017, 18-20.

J. Lipták: Bilder aus der Zipser Vergangenheit. Karpathen-Post 55, 1934, 6, 7.

E. Miroššayová: Südliche Kultureinflusse auf die Ostslowakei in der Hallstatziet. In: K. Herman/J. Vladár (red.): Rapports, co-rapports, communications tchécoslovaques pour le Ve congrès de l'Association internationale d'études de Sud-Est européen. Prague 1984, 21-36.

E. Miroššayová: Osídlenie Spiša v dobe halštatskej. In: S. Czopek/A. Hadała (ed.): Ziemie polskie we wczesnej epoce żelaza $i$ ich powiazania $z$ innymi terenami. Rzeszów 1992, 133-138.

E. Miroššayová: Einflüsse der Hallstattkultur in der Slowakei. In: E. Jerem/I. Poroszlai (ed.): Archaeology of the Bronze and Iron Age. Archaeolingua 9. Budapest 1999, 157-166.

B. Novotný/M. Novotná/M. Kovalčík: Popradská kotlina v dávnej minulosti. Košice 1991.

K. Pieta: Die Púchov Kultur. Nitra 1982.

K. Pieta: Die Siedlung Liptovská Mara II und die Anfänge der Einflüsse der Latène-kultur im Westkarpatenraum. Slovenská archeológia 48, 2000, 315-346.

K. Pieta: Spiš vo včasnej dobe dejinnej. In: R. Gładkiewicz/M. Homza (ed.): Terra Scepusiensis. Stav bádania o dejinách Spiša. Levoča - Wrocław 2003, 149-158. 
Pieta 2008

Roth 2003

Soják 1998

Soják 2015

Soják/Fecko 2012

Spöttl 1885

Šalkovský 2002

Tankó 2005
K. Pieta: Keltské osídlenie Slovenska. Mladšia doba laténska. Nitra 2008. P. Roth: Osídlenie Spiša vo včasnej dobe dejinnej. Dizertačná práca (Archeologický ústav SAV). Nitra 2003. Nepublikované.

M. Soják: Regionálny prieskum Spiša. Archeologické výskumy a nálezy na Slovensku v roku 1996, 1998, 148, 149.

M. Soják: Diadém typu Istebné. Študijné zvesti Aú SAV 57, 2015, 141-166.

M. Soják/P. Fecko: Sídlisko púchovskej kultúry v Spišskom Hrhove na Spiši. In: G. Březinová/V. Varsik (ed.): Archeológia na prahu histórie. K životnému jubileu Karola Pietu. Nitra 2012, 247-262.

I. Spöttl: Von der Donau zur Popper. Jahrbuch des Ungarischen Karpathen-Vereines 12, 1885, 42-51.

P. Šalkovský: Výšinné hradisko v Detve - protohistorické osídlenie. Slovenská archeológia 50, 2002, 99-126.

K. Tankó: Horn Handled bowls of the Central Europe Iron Age. In: H. Dobrzański/V. Megaw/P. Poleski (eds.): Celts on the Margin. Kraków 2005, 153-162.

http://mapire.eu/hu [20. 03. 2018].

http://www.podnemapy.sk] [15. 02. 2018].

\title{
Preliminary evaluation of ceramic collection from Jerusalem hill site in Kežmarok
}

\author{
Andrea Námerová - Marta Kučerová
}

\section{Summary}

Jerusalem hill (Jeruzalemský vrch) situated on the outskirts of the town Kežmarok belongs to important archaeological sites in the Spiš region. The site has been identified at the latest in the $19^{\text {th }}$ century, but has never been studied systematically. The largest part of the material remains can by ascribed to the Iron Age - to the Púchov culture more precisely. The area is known as a place with particularly large amount of pottery findings. Unfortunately the large part of this pottery comes from archaeological field collection. In the 1970s this site was destroyed by construction of a sports complex (Hotel Šport and its facilities) and an open-air theatre the most part. The study focuses on pottery finds, spindle whorls, ceramic wheels, or other objects made from clay. Most of the pottery belongs to the Púchov culture, small part comes from the Pre-Púchov phase. At the site also potsherds of possible, but hardly dated horn - handle bowls, or jugs have been found. These are characteristic for the Late Hallstatt and the Early La Tène, found in Slovakia as well as in other regions in Central and South Europe. Similar jugs are recorded also from others fortified settlements in the Spiš region (for example Hrabušice-Zelená hora, Nová Lesná-Hliník, etc.). In general we have selected decorated pottery mostly also decorated rims, bodies, bottoms. A large majority of ceramics belongs to the Púchov culture. In some cases (decorated pottery and whorls) analogies from a wider area of the Púchov culture, or the pre-Púchov phase, even the Late Hallstatt period have been pointed out. The results presented in this study are not definitive. Our preview is subject to further study, deeper analysis and comparing material, mainly from other Spiš sites and in a broader context (Poland, Liptov and other regions). The theme of settlement and stratification of cultural layers of prehistoric settlement of Jerusalem Hill has not been exhausted and until now it has only a limited basis as a result of a missing systematic archaeological research.

Fig. 1. Kežmarok, Jeruzalemský vrch (Kežmarok distr.). Topographic map 1 : 10000 with marked sites of archaeological and other excavations. 1 - amfiteáter/amphitheatre (archaeological excavations; Kučerová 2017); 2 - hotel Štart (archaeological excavations; Giertlová 1998a; 2000; Kučerová 2017); 3 - plynová ryha pod hotelom Štart/gas pipeline trench below the hotel Štart (cross-section of the terrace; Giertlová 2000); 4 - medzi zjazdovkami, SV od hotela Štart/ between ski slopes, NO of the hotel Štart (trench with the find of vessel; Kučerová 2016); 5 - strelnica/shooting-rangeOravcova lúka (ground plot No. 1476, archaeological excavations; Giertlová 1998b); 6 - strelnica/shooting-rangeOravcova lúka (ground plot No. 1462, archaeological excavations; Giertlová 1998b). 
Fig. 2. Kežmarok, Jeruzalemský vrch (Kežmarok distr.). Cross-sections of archaeological trenches from 2000, 2013, 2016 (drawing M. Kučerová). 1 - Jeruzalemský vrch, hotel Štart, excavations 2013 (Fig. 1, site 2), trench III, north crosssection; 2 - Jeruzalemský vrch, hotel Štart, excavations 2000 (Fig. 1, site 2), trench II, north cross-section; 3 - Jeruzalemský vrch, gas pipeline trench below the hotel Štart, excavations 2000 (Fig. 1, site 3), north cross-section (vertical cross-section through the terrace); 4 - Jeruzalemský vrch, between ski slopes, NO of the hotel Štart, excavations 2016 (Fig. 1, site 4), north cross-section with the find of vessel.

Legend: 1 - top soil; 2 - grey light brown silty sand; $2 \mathrm{~A}$-friable light grey brown silty sand; 3/3A - light grey brown clay with sandstones; $4 / 8$ - friable mid brown silty sand; 9 - soft light grey brown to orange brown clay; 10 - soft light brown silty sand; $12 / 13$ - friable to loose light grey brown silty sand; 14 - hard drak grey clay with charcoal; 16 - very hard grey brown sandy clay (probably mixed layers 14 and 17); 17 - friable to loose light yellow silty sand with charcoal and animal bones; 19 - loose light grey brown silty sand; 20 - consistent soft mid brown silty sand with inclusions of yellow clays; 21 - friable dark brown silty sand with occasional sandstones; 22 - very hard grey clay; 23 - hard light sandy clay; 24 - very hard dark grey to brown clay; 25 - friable red brown sandy silt; 26 - very hard light grey clay; 27 - hard brown to red brown sandy clay with charcoal and red burned sandstones; 28 - very hard grey clay with occasional charcoal and sandstones; 29 - very hard dark brown clay; 2.1.A - friable grey red clay with burned clay and charcoal; 2.4.A - friable grey brown clay; 12/13A - consistent soft gray black clay with occasional burned clay; 14A - consistent light grey clay with frequent burned clay and charcoal; 16A - consistent brown cley with frequent charcoal, burned clay sand sandstones; $16 \mathrm{~B}$ - consistent gray black clay; 25A - hard grey red brown clay with occasional burned clay; 25B - hard grey clay; 27A - hard grey red brown clay; 27B - hard burned brown red clay; $27 \mathrm{C}$ - hard burned red brown clay; $28 \mathrm{~A}$ - very hard grey clay with charcoal; $29 \mathrm{~A}$ - very hard brown to 'rusty' brown clay; $2 \mathrm{~B}$ - dark brown clay with charcoal; 2C - consistent dark grey clay; $3 \mathrm{~B}$ - very hard layer of withered sandstone, small fragments glued with clay; $\mathrm{P}$ - bedrock (mainly withered sandstone); $\mathrm{K}$ - stone; $\mathrm{m}$ - burned clay; $\mathrm{u}$ - charcoal.

Pl. I. Kežmarok, Jeruzalemský vrch, site hotel Štart (Kežmarok Distr.). Archaeological research in 2013, selection of findings (drawing M. Kučerová).

Pl. II. Kežmarok, Jeruzalemský vrch, site hotel Štart (Kežmarok Distr.). Archaeological research in 2013, selection of findings. Scale: a - 1-6; b-7, 8; c-9-14 (drawing M. Kučerová).

Pl. III. Kežmarok, Jeruzalemský vrch (Kežmarok Distr.). Selection of findings. 1, 2, 6 - site hotel Štart (archaeological research in 2013); 3-5 - M. Greisiger's findings collection (Museum in Kežmarok). Scale: a - 1, 2; b - 3-6 (drawing M. Kučerová, photo A. Námerová).

Pl. IV. Kežmarok, Jeruzalemský vrch, site hotel Štart (Kežmarok Distr.). Archaeological research in 2013, selection of findings (drawing M. Kučerová, photo A. Námerová).

Pl. V. Kežmarok, Jeruzalemský vrch, site hotel Štart (Kežmarok Distr.). Archaeological research in 2013, selection of findings (drawing M. Kučerová, photo A. Námerová).

Mgr. Andrea Námerová, PhD.

Záhrebská 3

SK - 81105 Bratislava

andrea.namerova@gmail.com
Mgr. Marta Kučerová

Múzeum v Kežmarku

Hradné námestie 42

SK - 06001 Kežmarok

archeolog@kezmarok.com 
